Kończące tom glosy w dyskusji należały do: Wiesława Rogalskiego, Barbary Smolińskiej-Theiss, Zofii Zukowskiej, Mariusza Cichosza, Danuty Urbaniak-Zając i Jacka Piekarskiego. Treść tych wystapień i ożywiona wymiana poglądów wskazują jasno, iż prezen- towana książka jest jedynie wstẹpem do szerszej dyskusji i refleksji nad współczesną pedagogika społeczną I taka chyba była intencja redaktorów omawianego wydawnictwa.

Edyta Glowacka

\title{
Andrzej Meissner, Spór o duszę polskiego nauczyciela. Spoleczeń- stwo galicyjskie wobec problemów ksztalcenia nauczycieli, Rzeszów 1999, Wyd. Wyższej Szkoly Pedagogicznej, ss. 380
}

Z uznaniem trzeba przyjąc książke profesora Andrzeja Meissnera, zajmującego się dziejami oświaty w Galicji, zatytułowaną Spór o dusze polskiego nauczyciela. Spoleczenistwo galicyjskie wobec problemów ksztalcenia nauczycieli.

Publikacja stanowi 11 tom z serii Galicja $i$ jej dziedzictwo, w której autor podejmuje problematykę kształtowania się systemu kształcenia nauczycieli.

Jak pisze autor ksztaltowanie się współczesnego modelu szkół pedagogicznych miało miejsce w XIX w. w zwiazzk z rozwojem obowiązującej i ogólnoksztalcącej oświaty elementarnej traktowanej jako pierwszy szczebel nauczania $i$ torującej droge dalszej edukacji. Wymagało to przygotowania nauczycieli tak pod względem teoretycznym, jak i pedagogicznym.

Społeczeństwo polskie, pozostajace pod panowaniem trzech obcych państw, nie mogło decydować o kształcie szkolnictwa pedagogicznego, które podporzadkowane zostało systemowi oświatowemu zaborców.

Największe możliwości kształtowania rodzimej oświaty pojawiły się w zaborze austriackim w latach 60-tych XIX w. Kształcenie nauczycieli dla szkół ludowych stało się problemem nie tylko oświatowym, ale i politycznym. Whadze polityczne zdawały sobie sprawę, że dzięki powszechnemu nauczaniu elementarnemu, można kształtować poglady społeczne, wpajać określone wartości i wdrażać do pewnych określonych zachowań politycznych. W tym kontekście osoba nauczyciela nabierała szczególnego znaczenia. Autor w tytule książki - jak sądzę
- odwołuje się do dawidowskiej koncepcji osobowości nauczyciela, zawartej w rozprawie pt. O duszy nauczycielstwa, opublikowanej przez H. Rowida na łamach „Ruchu Pedagogicznego". J. W. Dawid dowodził w niej, że nauczyciel ma działać na ucznia jak człowiek na człowieka. Walka o rzad dusz nauczycielskich, szczególnie w Galicji, stała się jednym z bardzo ważnych elementów polityki oświatowej prowadzonej przez władze krajowe.

Dalsze zmiany $w$ dziedzinie elementarnej edukacji dokonaly się na początku XX w. (tuż przed I wojnz światowa) pod wplywem idei „Nowego Wychowania". Nauczyciela powinna "echować aktywność i twórczość zawodowa oraz dążenie do doskonalenia umiejętności nauczycielskich. Dyskusje w tej sprawie podejmowały różne środowiska społeczne, partie polityczne $i$ ich organy prasowe, jak również organizacje nauczycielskie, które najbardziej zainteresowane były prestiżem swojego zawodu.

System kształcenia nauczycieli dla potrzeb szkolnictwa galicyjskiego stanowił swoista mozaikę. $\mathrm{Na}$ wyróżnienie zasłużył niewątpliwie system kształcenia nauczycieli szkół ludowych, który był najbardziej zwarty organizacyjnie i programowo.

Intencja autora - jak sądze - było uzyskanie odpowiedzi na pytania: jak funkcjonował system kształcenia nauczycieli, w jakim stopniu relizowane były założenia tego systemu narzucone przez władze państwowe i krajowe, jak również, jakie efekty przynosiły założenia systemu kształcenia nauczycieli w wymiarze praktycznym i teoretycznym? 
Jak zaznacza autor seminaria nauczycielskie - podobnie jak i inne placówki oświatowe - funkcjonowały w określonej rzeczywistości społecznej, podlegały różnorodnym wplywom i modyfikowane były zarówno przez czynniki polityczne, jak i ekonomiczne. W dalszej kolejności Andrzej Meissner rozważa więc, w jakim stopniu uwarunkowania te wywierały wpływ na kierunek ksztalcenia przyszłych nauczycieli i czy przedstawiciele rożnych orientacji politycznych podejmowali walkę o zreformowanie istniejącego systemu kształcenia.

Aby nie zatracać całościowego obrazu poruszanej problematyki powyższe zagadnienia starano się omówić w kontekście założeń organizacyjnych i programowych, podstaw prawnych funkcjonowania seminariów oraz dyskusji nad modelem zakładów nauczycielskich.

Źródła archiwalne wykorzystane w książce do rekonstrukcji badanych zjawisk są bardzo zróżnicowane. Najcenniejsze, bo po raz pierwszy wykorzystane w badaniach dziejów seminariów nauczycielskich, okazały się akta Rady Szkolnej Krajowej i Namiestnictwa przechowywane w Centralnym Państwowym Archiwum Historycznym Ukrainy we Lwowie. Pozwalały one na rekonstrukcję urzędowego wizerunku szkolnictwa pedagogicznego. Zawierały sprawozdania powizytacyjne seminariów nauczycieIskich, sprawozdania dyrekcji seminariów z działalności dydaktyczno-wychowawczej, akta personalne, dane dotyczące wyposażenia szkół, finansów, a także korespondencję z Ministerstwem Wyznań i Oświecenia w Wiedniu. Cenne źródło stanowiły materiały z Archiwum Głównego Akt Dawnych w Warszawie, zawierajace akta personalne i korespondencje dotyczące zagadnień osobowych nauczycieli seminaryjnych. Niewiele informacji dostarczyly częściowo zachowane akta z Archiwum Państwowego w Przemyślu, Rzeszowie, Tarnowie i Krakowie.

Bardzo cenne okazały się również materiały źródłowe drukowane: sprawozdania roczne dyrekcji seminariów nauczycielskich, sprawozdania Rady Szkolnej Krajowej o stanie wychowania publicznego, stenogramy Sejmu Krajowego, wydawnictwa statystyczne, pamiętniki i relacje nauczycieli $\mathrm{i}$ wychowanków seminariów, znajdujące się w rękopisach, jak i wydane drukiem. Wiele informacji o seminariach nauczycielskich zamieszczała prasa pedagogiczna: „Szkoła" i „Rodzina i Szkola". Dla scharakteryzowania kadry pedagogicznej seminariów nauczycielskich niezwykle przydatne okazały się materiały biograficzne zawarte w słownikach, encyklopediach, wydawnictwach okolicznościowych i prasie pedagogicznej.

Sądz̨, że na szczególną uwagę i podkreślenie zasługuje odtwarzanie sylwetek kadry pedagogicznej zakładów nauczycielskich. Poznanie ich motywów i sposobów działania pozwoliło wyjaśnić procesy dokonujące sie w tych zakładach.

Aby przedstawić dorobek pedagogiczny kadry nauczającej poddano analizie prace pedagogiczne wydane $w$ formie opracowań książkowych lub rozpraw i artykułów zamieszczanych w czasopismach pedagogicznych.

Uważam, że omawiana praca posiada charakter nowatorski. Autor dokonał wnikliwej i rzetelnej analizy zebranych materiałów ukazując wnikliwie problematykę systemu kszałcenia nauczycielskiego w społeczeństwie galicyjskim. Zgromadzono obfity i niezwykle cenny materiał, który analizowano i interpretowano zgodnie $\mathrm{z}$ przyjętymi założeniami. Zwraca uwage przemyślany układ pracy, pozwalajcy na kompleksowe rozważania.

Praca składa się z siedmiu rozdziałów, w których omówiono kolejno formowanie się systemu kształcenia nauczycieli w Europie, następnie w Galicji, omówiono zakłady kształcenia nauczycieli (państwowe i prywatne seminaria nauczycielskie), warunki materialne funkcjonowania seminariów, realizację procesu kształcenia i wychowania kandydata do zawodu nauczycielskiego. Przeprowadzono także charakterystykę zespołów nauczycielskich wraz z dyrektorami szkół, od których niewątpliwie zależał stopień realizacji przyjętych założeń. Całość pracy zamykają aneksy zawierające dane o warunkach lokalowych seminariów $\mathrm{i}$ internatów, wykaz prywatnych seminariów nauczycielskich, a także informacje o dyrektorach i kadrze nauczającej. Zamieszczono również wybór dokumentów do dziejów seminariów nauczycielskich znajdujących się w Centralnym Państwowym Archiwum Historii we Lwowie oraz indeks nazwisk. 
Wyniki badań wykazały, że dzieje seminariów nauczycielskich można podzielić na trzy wyodrębniające się okresy. Pierwszy trwał od ich powstania do $1890 \mathrm{r}$. W okresie tym poczqtki funkcjonowania seminariów były niezwykle trudne $\mathrm{i}$ wynikały $\mathrm{z}$ narzuconej przez władze oświatowe państwa zaborczego koncepcji kształcenia nauczycieli, o czym już wspominałam. Do tego dołączały się trudności lokalowe i kadrowe, a także brak wypracowanych metod i form pracy dydaktyczno-wychowawczej.

Drugi okres to lata 90-te XIX i początek $\mathrm{XX}$ wieku,. charakteryzujące się rozwojem szkolnictwa ludowego oraz wzrostem zapotrzebowania na kwalifikowanych nauczycieli. Powstają prywatne seminaria, które stają się konkurencją dla zakładów państwowych. W okresie tym znacznej poprawie uległ zakres i poziom wykształcenia, lecz proces dydaktyczny opierał się na wskazaniach dydaktyki herbartowskiej.

Natomiast trzeci okres (1907-1918) przyniósł dezintegrację systemu kształcenia nauczycieli.

Problemy kształcenia nauczycieli wyzwalały dyskusje i polemiki wśród polityków, działaczy nauczycielskich, na łamach prasy czy czasopism, szczególnie pedagogicznych. Dla jednych nauczyciel był rękojmią zachowania istniejącego porządku społecznego, dla innych motorem postępu i przemian, jakie należało dokonać w świadomości spoleczeństwa galicyjskiego.

Walka a dusze polskiego nauczyciela angaźowała administrację szkolną i działaczy oświatowych. Mimo, że kształcenie nauczycieli przeszło swoista ewolucje od preparand do szkoły średniej zakończonej matura, to koncepcja kształcenia nauczycieli nie wytrzymała próby czasu i już pod koniec XIX w. seminaria wymagały gruntownej reformy. Dzięki toczacym się polemikom i dyskusjom nastąpiła jednak przebudowa świadomości spoleczeństwa galicyjskiego, które było coraz bardziej przekonane o kulturotwórczej roli oświaty i decydującym znaczeniu nauczyciela jako animatora życia kulturalnego.

Reasumując pragnę zaznaczyć, że przeprowadzone analizy pozwolity na sformułowanie ogólnych i cząstkowych odpowiedzi na podjęty w badaniach problem. Autor wniósł do pracy wiele własnych oryginalnych przemyśleń. Do- wodzi to niezbicie walorów społecznych i wartości intelektualnej książki, którą czyta się doskonale.

Malgorzata Posluszna

W serii wydawniczej „Galicja i jej dziedzictwo", publikowanej przez Wydawnictwo Wyższej Szkoły Pedagogicznej w Rzeszowie, ukazał się 11 tom autorstwa Profesora Andrzeja Meissnera zatytułowany Spór o dusze nauczyciela. Spoleczeristwo galicyjskie wobec problemów ksztalcenia nauczycieli.

Jest to kolejna $\mathrm{z}$ wielu publikacji tego Autora poświęcona problematyce zawodu nauczyciela w ciągu dziejów. Należy przypomnieć przynajmniej dwie z nich, sq to: Ksztalcenie nauczycieli $w$ środkowej Galicji 1871-1914 (1974) oraz Ksztalcenie nauczycieli w środkowej Malopolsce 1918 -1939 (1977).

Omawiana praca składa się z 7 rozdzialów, uzupełniają je Aneksy i Źródła do dziejów seminariów nauczycielskich. Do jej przygotowania została wykorzystana bogata literatura przedmiotu oraz źródła drukowane, wśród nich wydawnictwa urzędowe, sprawozdania szkolne, regulaminy, statuty, podręczniki i przewodniki, a także pamiętniki i wspomnienia. W znacznej części publikacja została przygotowana w oparciu o materialy archiwalne. Na szczególną uwage zasługuje wykorzystanie przez Autora akt Rady Szkolnej Krajowej znajdujących się w Centralnym Państwowym Archiwum Historycznym we Lwowie.

W swojej pracy A. Meissner odpowiada na kilka pytań, m.in.: Jakie miejsce zajmowały seminaria nauczycielskie $w$ systemie oświaty? Jaką ewolucję przeszły te instytucje na przestrzeni omawianego okresu? Czy spełniały one swoja rolę? Jakie zadania stawiano nauczycielom w toczących się dyskusjach na ten temat? Jaki wypracowano model nauczyciela?

Zagadnienia te, będące odpowiedziami na postawione pytania, staly się przedmiotem refleksji $w$ poszczególnych rozdziałach.

Rozdział I pt. Formowanie sie systemu ksztalcenia nauczycieli w Europie w XIX i na 